\title{
The Effect of Teaching Discourse Markers (DMs) on Speaking Achievement among Iranian Intermediate EFL Learners
}

\section{Ashraf Khandaghi Khameneh ${ }^{1} *$ \& Laleh Fakhraee Faruji ${ }^{1}$}

\section{* Correspondence: \\ ashrafkhandaghi@yahoo.co.uk \\ 1. Department of English Language \\ Teaching, Shahr-e-Qods Branch, \\ Islamic Azad University, Tehran, Iran}

Received: 21 June 2020

Revision: 31 August 2020

Accepted: 4 October 2020

Published online: 20 December 2020

\section{Abstract}

This study aimed to investigate the effect of teaching discourse markers (DMs) on Iranian intermediate EFL learners' speaking achievement. In the first step, 60 homogeneous intermediate students out of 110 were chosen from a private English language institute and randomly divided into two equal groups, namely an experimental group and a control group. Then they were pretested through a researcher-made speaking test. During the treatment, the experimental group was taught DMs by conversations. Then, they found the DMs in transcriptions of conversations. Also, the researcher used a researcher-made booklet containing the instructional materials related to DMs to be taught to the learners. On the other hand, there was not any direct instruction to DMs to the students in the control group. They only narrated the assigned storybook, and performed conversations by role play. These posters were used based on the related topics of the learner's textbooks. After the treatment which took 12 sessions, the researchers administered the modified version of the mentioned pre-test as the post-test to find out the effect of the treatment on the participants' speaking achievement. When the data were collected, Independent and Paired Samples t-tests were run to analyze them. The results showed that there was no significant difference between experimental and control group in the posttest. Indeed, the findings indicated that teaching discourse markers (DMs) did not have any effect on Iranian intermediate EFL learners' speaking achievement.

Keywords: discourse, discourse markers, intermediate EFL learners, pragmatic, speaking achievement 


\section{Introduction}

Speaking is an interactive process which leads to constructing meaning that involves the development of a particular type of production, reception, and information processing in its typical grammatical, lexical, and discourse patterns (Burns \& Joyce, 1997). That is why Webb (1982) believed that oral practice is necessary for speaking. For most people the ability to speak a language is synonymous with knowing that language, since speech is the most basic means of human communication (Lazaraton, 1996). In fact, when you are asked to speak English, you are expected to carry on a conversation reasonably and competently (Brown, 2001). In this regard, discourse markers play a fundamental role.

Discourse Markers (DMs) are words and phrases used in speaking and writing to signpost discourse. Discourse markers do this by showing turns, joining ideas together, showing attitude, and generally controlling communication. Some people regard discourse markers as a feature of spoken language only (Namaziandost \& Shafiee, 2018). Discourse markers are an important feature of both formal and informal native speaker language. The skillful use of discourse markers often indicates a higher level of fluency and an ability to produce and understand authentic language.

DMs are important features of spoken language in terms of their frequency and multi-functionality in spoken discourse. They are commonly preferred discourse items used by particularly native speakers of English. That is why Quirk (1955) stated that they are sharing devices and intimacy signals in our everyday talk in spoken discourse. DMs have the role of smoothing spontaneous interaction between speakers and also facilitating comprehension of the hearers. Thus, if second language (L2) learners want to have a more natural and native-like speech, they should adopt DMs and apply them properly in their speech (Fuller, 2003).

Several terms such as discourse marker (Schiffrin, 1987), pragmatic marker (Fraser, 1990), discourse particle (Schourup, 1985), pragmatic particle (Ostman 1981), pragmatic expression (Erman, 1987), and connectives (Blakemore 1987) were coined and used by some researchers to name the linguistic items that are used as connectors of sentences in discourse. However, the term DMs is the most common one employed by most researchers who work on English discourse. In spite of the argument on an appropriate term which can best describe these types of connectors, there is no doubt that DMs play a salient role in the organization of a native speaker discourse.

According to Schiffrin (1987), "discourse markers are sequentially dependent elements which bracket units of talk" (p.31). However, Louwerse and Mitchell (2003) believed that, DMs mostly occur in spoken rather than written discourse. For example, Carter and McCarty (2006) listed the most common DMs in every spoken language which are single words such as: anyway, great, fine, good, like, now, ok, right, so, well, as well as phrasal and clausal items such as: you know, I mean, as I play, for a start, and mind you. Furthermore, DMs are also known as optional elements in spoken discourse.

Moreover, there has been considerable debate about whether teachers need to teach these forms to students wishing to be successful users of English (Namaziandost, Rezvani, \& Polemikou, 2020; Prodromou, 2008), particularly those using English in lingua franca contexts. Timmis (2012) suggests that the debate revolves around the link between native speaker usage and cultural identity. A spoken corpus based upon native speaker data may tell us the most frequent forms in use but some of these may be linked directly to a particular cultural identity and therefore may not be the most useful items for learners.

However, as Timmis (2012) also acknowledges, there have been few empirical studies which have investigated the teaching and learning of spoken grammar in classroom contexts. This suggests that research which investigates how to best teach forms which could help learners to become SUEs is worthwhile, providing the forms chosen are appropriate for the context in which learning takes place. DMs are not highly idiomatic and do not seem to be a mark of cultural identity in the way that slang or colloquial language can be and are therefore likely to be worth acquiring for productive use in English as a Second Language (ESL) classrooms. Data from spoken corpora indicate that DMs are very common in (at least) native speaker speech. 'You know' and 'I mean', for example, are the first and second most frequent two-word chunks in the CANCODE spoken corpus of British English (Namaziandost, Hosseini, \& Utomo, 2020; O'Keeffe, McCarthy, \& Carter, 2007). The frequency of DMs is as a result of them having a number of useful functions in speech such as showing listenership or opening conversation but their high frequency may also mean that they do not always stand out and can seem banal or irrelevant to learners (Jones, 2010; Namaziandost, Pourhosein Gilakjani, \& Hidayatullah, 2020). Despite this, they rarely appear in textbooks (Cullen \& Kuo, 2007; Namaziandost, Shatalebi, \& Nasri, 2019) and have only occasionally been the subject of classroom research. 


\subsection{Statement of the Problem and Purpose of the Study}

English is spoken widely internationally and having the ability to speak the language enables one to communicate in most parts of the world (Simin \& Tavangar, 2009). One of the important indices of second/foreign language learners' communicative competence is the ability to form a coherent discourse and maintain discourse cohesion (McCarthy, 1993).

As a teacher, the researchers have observed problems in conversation because students don't use DMs properly in their speaking. Because of the main functions that DMs have in speech and communication, their misuse in conversation can lead to semantic or pragmatic misunderstanding. Sun (2013) stated that in spite of the students' realization of importance of DMs in the language learning, they can't use them well in everyday talk, which indicates that more help, guidance, and instruction from teachers are needed and in terms of the students more attention and exercise are necessary in order to obtain the automatic application of these DMs.

Shen Ying (1998) reported that DMs have not been included in the EFL curricula seriously in spite of the significant role they play in spoken discourse and English as a Foreign Language (EFL) learners have had various problems in organizing their sentences into a coherent unified whole. This problem might be the result of the fact that each language has its own unique system of conveying meaning through oral discourse and since language learners try to transfer their first language (L1) system into the L2 system, they have problems in managing their speech in a smooth and natural way. De Klerk (2005) believed that it might be because of "their lack of clear semantic denotation and systematic role, which makes formal or explicit commentary on their use fairly difficult" (p.275).

As stated by Hellermann and Vergun (2007) native speaker's discourse contains a number of discourse structuring devices that make their speech more comprehensible to their listeners. However, a lack of discourse cues in non-native discourse creates communication problems for native listeners; moreover, most studies done on DMs in Iran have addressed the listening and reading skills; however, little research has been conducted on speaking. Therefore, due to the lack of sufficient research on the effect of teaching DMs on speaking and willingness to communicate, a serious need for more researches in this regard was felt and this study was an attempt to investigate whether EFL learners' speaking and willingness to communicate can be influenced by teaching DMs. In fact, in this study attempts were made to explore the effect of teaching DMs on EFL learners' speaking achievement. Put it in more tangible terms, the purpose of the study was to investigate the effect of teaching DMs on EFL learners' speaking achievement and willingness to communicate. Moreover, knowledge of DMs can be made more significant in terms of variety and their functions in spoken discourse (Frung \& Carter, 2007; Muller, 2005). Wierzbicka (1991) stated that DMs are one of the significant items which help language learners use language culturally, socially, and appropriately to maintain cohesion and effectiveness in their discourse and interpersonal interaction. Previous research indicated that EFL learners use a limited number and less varied DMs in their spoken English (Asic \& Cephe, 2013; Helerman \& Vergum, 2007; Lam, 2009). Accordingly, the current research attempts to address the mentioned problem. The findings of this study may help EFL learners to develop their communicative competence and abilities much more efficiently.

\subsection{Research Question}

Regarding the mentioned points, this study aimed to answer the following research question:

RQ. Does teaching DMs have any significant effect on intermediate EFL learners' speaking achievement?

\subsection{Research Hypothesis}

With regard to the above-stated question, the following null hypothesis was suggested:

H0. Teaching DMs does not have any significant effect on intermediate EFL learners' speaking achievement.

\section{Review of the Literature}

Conversation has been of primary interest to language researchers. Since everyday conversation is the most occurring language use, Conversation Analysis (CA) has been highly considered among other approaches in speaking. Scholars have developed CA for a particular paradigm in the study of naturally occurring language use. According to CA, it is possible to analyze talk-in-interaction by examining its recordings alone. Therefore, CA focuses on analyzing talk produced in interactions, and how participants systematically organize their interactions to solve the problems of understanding. A great deal of communicative activity consists of routine formulas that are usually fixed-expressions. According to Wray (2000), formulas refer to a sequence, continuous or discontinuous, of words or other meaning 
elements; which is, or appears to be, prefabricated; that is, stored and retrieved whole from memory at the time of use, rather than being subject to generation or analysis by the language grammar.

Meanwhile, every language has its own specific DMs including gambits and fillers. Various types of DMs are unconscious devices that serve as a pause in the middle of sentences as the speaker gathers his or her thoughts, but wants to maintain the listener's attention. DMs, in fact, add nothing to the conversions, they just help speaker to think more and organize his speaking (Yazdizadeh, Shakibaei, \& Namaziandost, 2020). As words and phrases used in speaking and writing to 'signpost' discourse, DMs is useful by showing turns, joining ideas together, showing attitude, and generally, controlling communication. Some people regard DMs as a feature of spoken language only. Skillful use of DMs often indicates a higher level of fluency and an ability to produce and understand authentic language. In the literature, the problem of the students who cannot communicate appropriately has been considered by many researchers. Accordingly, the effect of using DMs on speaking ability has been considered in this study.

To communicate English efficiently, EFL learners should develop their skills in writing, reading, speaking, and listening. However, many EFL learners pay more attention to speaking skill than other ones because people who know the language are referred to as "speakers" of that language. According to Celce- Murcia (2014), L2 speaking skills are not only critical for communication within the L2 classroom but they are necessary for communication both inside and outside the English-speaking context. ESL/EFL teachers will want to do whatever they can to advance the development of fluent, accurate, appropriate, and authentic language on the part of their learners. This effort will require understanding of the nature of speaking fluency, the principle of error correction, the elements of pragmatic appropriately, and the findings from corpus-based research, so that the teachers will be able to plan and deliver lessons and activities that promote oral communication skills. Meanwhile, fluent speaking provides speaker with several advantages such as efficient expression of one's thoughts, opinions, and feelings as well as drawing the audience's attention to better understand his/her speech.

Fung and Carter (2007) compared the DMs produced by native speakers and English learners based on a pedagogic sub-corpus from CANCODE, a corpus of spoken British English, and a corpus of interactive classroom discourse of secondary pupils in Hong Kong. The researchers reported that in both groups, DMs are very useful to structure and organize speech on interpersonal, referential, structural, and cognitive levels. In the Hong Kong learners, it was observed a liberal use of referentially functional discourse markers (e.g. but, and, ok, etc., so); however, they less used other markers. Also, they reported that native speakers employed DMs for a wider variety of pragmatic functions.

In another study, Farhat, Asim Rai, and Arif (2011) conducted a corpus-based study on DMs in British and Pakistan. For this purpose, the researchers explored the frequency of eight DMs including I mean, you know, I think, kind of, sort of, well, you see, and so in British and Pakistani speakers' speeches. As they concluded, compared to non-native speakers, native speakers more frequently use DMs in their speeches. Further, DMs occurs at all positions in Pakistani speeches, i.e., initial, medial and final speeches. In Pakistani spoken language, these DMs may function as fillers, show agreement or polite disagreement, show surprise, etc.

In addition, Asik and Cephe (2013) explored DMs production and spoken language. In their study, two specific corpora were used. The corpus included transcriptions of the course presentations of twenty native and non-native undergraduate students studying at an English Language Teaching (ELT) program in Turkey. The transcripts of student presentations of native speakers were attained using MICASE Corpus to compare the data. Then, the researchers specified the occurrences of the DMs in both corpora with frequency analysis. As found, a limited number and less variety of DMs was used by non-native speakers of English in their spoken English. It was also implied that it is critical to raise non-native speakers' awareness of using DMs in their spoken English.

In a study conducted by Jarret (2014), the relation between using speech fillers and personality was investigated. As found, younger people, and among women versus men more frequently employ DMs. He also reported that the gender difference was only present in teen and student participants, and had disappeared from age 23 and up. In addition, people with a more conscientious personality more frequently employed DM. In 2014, Sadeghi and RamezanYarandi analyzed the relation between DMs and speaking fluency of EFL learners. In this regard, they selected two groups of EFL students. In the first group, different DMs were presented in five sessions. Five conversation texts were administered in both groups and they were asked to retell these conversations by own wording on the next session. After recording, the number of DMs and speech disfluencies used by speakers of each group was counted and recorded for retelling the same conversation text. As they concluded, applying DMs intrinsically takes more time and whereas 
our definition about the fluency is based on the amount of time required to deliver one correct information unit, applying DMs cannot be effective.

Moreover, Tsai and Chu (2015) explored the effect of DMs on speaking fluency of Chinese learners. To this end, 17 Chinese learners and 5 native Chinese teachers' speaking during 220 minutes of courses was transcribed. The data collected from transcriptions included the data drawn from the learners who were learning English as second language, living in Taipei, Taiwan (a Chines speaking context) and the learners living in non-Chines speaking countries as EFL learners with little exposure to outside language. Analyzing the collected transcriptions, it was found that the frequency of DMs indicates speaking fluency in the target language. It was also found that understanding the ability of using DMs is a good way to assess spoken content richness as well as developing teaching methods.

Furthermore, Pazhakh and Karimi (2015) investigated the effect of explicit teaching of DMs on Iranian EFL learners' pragmatic fluency. To this end, fifty Iranian advanced EFL learners were selected from NICO language center of Ahwaz. The selected sample was randomly assigned to one experimental and one control group. The experimental group was familiarized with some types of DMs explicitly by the use of some examples. No DMs instruction was presented to the participants in the control group. They were only asked to memorize the conversations and do the role plays. At the end of the treatment, in order to see the effect of the DMs instruction on the learner's oral fluency, the learners in the two groups had a conversation on a selected topic. According to the percentage of using DMs in their aural production, it was concluded that the experimental group outperformed the control group.

Khaghaninejad and Mavadat (2015) studied the implementation of English DMs in academic papers written by Persian and English dentistry researchers. For the purpose of the study, the researchers analyzed twenty papers by Persian authors and twenty papers by English-speaking authors. The results showed that English-speaking researchers more frequently employed DMs in their papers. However, both groups employed almost an equal range of DMs in their papers. Also, among different sections of papers and under different sub-classes of DMs, discourse marker distribution was almost similar in the two groups. On the contrary, the papers written by Persian authors were not coherent due to underuse and misuse of DMs in these papers.

Reviewing the literature, it was demonstrated that numerous studies have been done on teaching discourse markers, though to the best researchers' knowledge rare studies carried out in Iranian context on the effect of teaching discourse markers (DMS) on speaking achievement among Iranian intermediate EFL learners.

\section{Methodology}

\subsection{Design}

Quasi- experimental method of research was used in this study. Accordingly, the study employs a pre-test and posttest design to extract needed data of one experimental group and one control group. This study focused on the variable of discourse markers (DMS) as an independent variable and speaking achievement a dependent variable which is hypothesized to be affected by the independent variable. The collected data were analyzed quantitatively through using Independent and Paired Samples t-tests.

\subsection{Participants}

To do this study, 60 students from a private English language institute in Andishe, Iran were selected out of 110 students as the target population of the study. They took a placement test and their proficiency was determined as intermediate level through an Oxford Quick Placement Test (OQPT). Their age range was between 16 and 19 years old and they were females since the researchers had access only to females. Indeed, the participants were selected based on convenience non-random sampling method. Then they were randomly divided into two groups of 30 , one experimental group (discourse markers group) and one control group.

\subsection{Instruments}

The first instrument which was utilized in the present study to homogenize the participants was OQPT. It helped the researchers to have a greater understanding of what level (i.e., elementary, pre-intermediate, intermediate) her participants were at. This test had 60 multiple-choice items and based on it the learners whose scores were 40 to 47 were intermediate students and were selected as the target participants of the study.

The second instrument was a researcher-made speaking pre-test. The researchers administered an interview based on the questions in units 1, 3, 4, 5, 7,9 and 12 of intermediate level English course book entitled English Result, developed 
by Hancock and McDonald (2013). Also, to homogenize the learners, the pretest results were considered. Their interviews were recorded for later scoring. The reliability of the pre-test was computed through inter-rater reliability by means of Pearson correlation analysis as $(\mathrm{r}=.880)$.

The third instrument was a speaking post-test. An interview (similar to the pretest in terms of format and number of items) was used as the post-test. The level of topics was the same in terms of difficulty in both pre and post-tests. The reliability of the post-test was calculated through inter-rater reliability by means of Pearson correlation analysis as $(\mathrm{r}=$ .817). It is worth noting that both pre-test and post-test were validated by 3 English experienced teachers. Before administering the final version of the pre and post-tests to the target population, they were piloted on the similar group on another English institute. The last instrument used in this study was a rating scale. The interviews of the learners were scored based on the rating scale developed by Luoma (2004) to check five items; Accuracy, Fluency, Range, Coherence, and Interaction.

\subsection{Data Collection Procedure}

To do the current study, first the researchers attended the English institute mentioned above and administered the OQPT in order to manifest the participants' homogeneity in terms of English language proficiency. Sixty participants out of 110 were selected for the target population of the present study. As stated before, the participants were divided into two groups; experimental group and control group. Afterward, the researchers administered the pre-test of speaking in order to check the speaking level of the participants before performing the treatment. Then, both groups received the treatment.

During the treatment, in the first step, the experimental group was taught DMs by listening to the conversation. In the experimental group, based on theme or topic of each lesson of the textbook, some conversations were selected. The learners should listen carefully to find the DMs in conversation. In the second step, they checked the transcriptions of conversation at the end of the book to find them. During the third step, the researchers explained more about the function of DMs that were used in conversation by researcher-made booklet. Each session, the researchers taught five kinds of DMs in the units.

Moreover, the learners in experimental group were divided into three groups of equal size in each class that was when all the learners were present, each group included five learners. Cooperation between learners was emphasized and encouraged by the researchers to better understand function of DMs. In the fourth step, one conversation was given to each group to listen and they were asked to find the DMs in it. After that, each group was asked to perform conversation by role-play. Then, the conversations were played to receive feedback from their peers and when necessary from the researchers. The final step involved doing homework for the next session. For example, the researchers asked the learners to read the story book. Then, the story had to be summarized by using DMs for the next session.

While the learners in the experimental group received such a treatment, the learners in control group did not receive any specific instruction regarding DMs. They only narrated the assigned storybook, listened conversations, and performed conversations by role play. The treatment took 15 sessions of 50 minutes each under the guidance of the supervisor. In the first session, the participants were homogenized. In the second session, the students were pre-tested. During 12 sessions, the students were taught by DMs, and in the last session the two groups took the speaking posttest. Then the data were analyzed to get the results.

\subsection{Data Analysis}

For answering the research question, after gathering the needed data the researchers analyzed the data with the help of SPSS (Statistical Package for Social Science) software version 25. Finally, Independent and Paired Samples t-tests were run to find out the effectiveness of teaching DMs on EFL learners' speaking achievement and also to compare the performance of control group with experimental group.

\section{Results}

Before carrying out any data analysis, it was needed to check the normality distribution of the data. One-Sample Kolmogorov-Smirnov Test was run in this regard. The results are presented in Table 1. 
Table 1. One-sample Kolmogorov-Smirnov test (Groups' pre and post-tests)

\begin{tabular}{llll}
\hline & Kolmogorov-Smirnov & & Sig. \\
\hline EG. Pre & Statistic & df & .119 \\
EG. Post & .177 & 30 & .089 \\
CG. Pre & .250 & 30 & .078 \\
CG. Post & .209 & 30 & .112 \\
\hline
\end{tabular}

Table 1 shows that the statistics of scores is normal $(p>.05)$ as the results obtained from using SPSS 25 . In this case, the parametric statistics like independent samples t-test and paired samples t-test can be used to get the final results.

Table 2. Group statistics (Pre-test of both groups)

\begin{tabular}{llllll}
\hline & Groups & $\mathrm{N}$ & Mean & Std. Deviation & Std. Error Mean \\
\hline Pre-test & EG & 30 & 12.2000 & 1.39951 & .25551 \\
& CG & 30 & 12.6667 & 2.02286 & .36932 \\
\hline
\end{tabular}

In Table 2, the descriptive statistics of both groups is presented. The means of both groups are almost equal. The EG's mean score is 12.2000 and the CG's mean score is 12.6667 . This means that the both groups are somehow similar since they are homogeneous at the beginning of the treatment.

Table 3. Independent samples t-test (Pre-test of both groups)

\begin{tabular}{|c|c|c|c|c|c|c|c|c|}
\hline & & \multicolumn{2}{|c|}{$\begin{array}{c}\text { Levene's Test for } \\
\text { Equality of } \\
\text { Variances }\end{array}$} & \multicolumn{5}{|c|}{ t-test for Equality of Means } \\
\hline & & $\mathrm{F}$ & Sig. & $\mathrm{t}$ & $\mathrm{df}$ & $\begin{array}{l}\text { Sig. (2- } \\
\text { tailed) }\end{array}$ & $\begin{array}{l}\text { Mean } \\
\text { Difference }\end{array}$ & $\begin{array}{l}\text { Std. Error } \\
\text { Difference }\end{array}$ \\
\hline \multirow[t]{2}{*}{$\begin{array}{l}\text { Pre- } \\
\text { test }\end{array}$} & $\begin{array}{l}\text { Equal variances } \\
\text { assumed }\end{array}$ & 8.924 & .004 & -1.039 & 58 & .303 & -.46667 & .44909 \\
\hline & $\begin{array}{l}\text { Equal variances } \\
\text { not assumed }\end{array}$ & & & -1.039 & 51.587 & .304 & -.46667 & .44909 \\
\hline
\end{tabular}

In Table 3, an independent samples t-test was used to show the scores of both groups on the pre-test. Since the Sig (.303) is greater than 0.05 , the difference between the groups is not significant at $(\mathrm{p}<0.05)$. In fact, they performed the same on the pre-test. 
Table 4. Group statistics (Post-test of both groups)

\begin{tabular}{llllll}
\hline & Groups & $\mathrm{N}$ & Mean & Std. Deviation & Std. Error Mean \\
\hline Post-test & EG & 30 & 16.6000 & 1.03724 & .18937 \\
& CG & 30 & 16.3000 & 1.14921 & .20982 \\
\hline
\end{tabular}

Table 4 reports the descriptive statistics of control and experimental groups in the post-test. The mean of the experimental group in the post-test is 16.6000 and the mean of the control group is 16.3000 . The means of the two groups are almost equal. However, there is a need to calculate the means through Independent Samples T-test to see if there was any significant difference. The results are presented in Table 5.

Table 5. Independent samples t-test (Post-test of both groups)

\begin{tabular}{|c|c|c|c|c|c|c|c|c|}
\hline & & \multicolumn{2}{|c|}{$\begin{array}{l}\text { Levene's Test for } \\
\text { Equality of Variances }\end{array}$} & \multicolumn{5}{|c|}{ t-test for Equality of Means } \\
\hline & & F & Sig. & $\mathrm{t}$ & $\mathrm{df}$ & $\begin{array}{l}\text { Sig. (2- } \\
\text { tailed) }\end{array}$ & $\begin{array}{l}\text { Mean } \\
\text { Difference }\end{array}$ & $\begin{array}{l}\text { Std. Error } \\
\text { Difference }\end{array}$ \\
\hline \multirow[t]{2}{*}{$\begin{array}{l}\text { Post- } \\
\text { test }\end{array}$} & $\begin{array}{l}\text { Equal variances } \\
\text { assumed }\end{array}$ & 1.437 & .236 & 1.061 & 58 & .293 & .30000 & .28264 \\
\hline & $\begin{array}{l}\text { Equal variances } \\
\text { not assumed }\end{array}$ & & & 1.061 & 57.401 & .293 & .30000 & .28264 \\
\hline
\end{tabular}

Table 5 indicates that the difference between the post-test of experimental and control groups is not significant at ( $p>0.05)$. According to the results of the Independent Samples t-test, the experimental group who received the treatment did not perform better than the control group in the post-test.

Table 6. Paired samples statistics (Pre and post-tests of both groups)

\begin{tabular}{llllll}
\hline & & Mean & $\mathrm{N}$ & Std. Deviation & Std. Error Mean \\
\hline Pair 1 & EX. Post & 16.6000 & 30 & 1.03724 & .18937 \\
& EG. Pre & 12.2000 & 30 & 1.39951 & .25551 \\
\multirow{2}{*}{ Pair 2 } & CG. Post & 16.3000 & 30 & 1.14921 & .20982 \\
& CG. Pre & 12.6667 & 30 & 2.02286 & .36932 \\
\hline
\end{tabular}

In Table 6, the performances of experimental and control groups are compared in the pre and post-test. Both groups were at the same level of speaking in both the pre-test and post-test. 
Table 7. Paired samples test (Pre and post-tests of both groups)

\begin{tabular}{lllllllll}
\hline & Mean & Std. Deviation & Std. Error Mean & t & df & $\begin{array}{l}\text { Sig. } \\
\text { tailed })\end{array}$ & $(2-$ \\
Pair 1 & $\begin{array}{l}\text { EX. Post - EG. } \\
\text { Pre }\end{array}$ & 4.4000 & 1.92264 & .35102 & 12.535 & 29 & .000 \\
Pair 2 & $\begin{array}{l}\text { CG. Post - CG. } \\
\text { Pre }\end{array}$ & 3.6333 & 2.26645 & .41379 & 8.781 & 29 & .000 \\
\end{tabular}

Based on the data presented in Table 7, the difference between the post-test and pre-test of the experimental group is significant since Sig (.000) is less than 0.05 ( $\mathrm{p}<0.05)$. The second t-test shows difference between the post-test and pre-test of control group is significant since Sig (.000) is less than 0.05 . Therefore, it can be concluded that both groups improved from pre-test to post-test which indicated that both method of instruction (i.e., teaching through DMs and traditional teaching) were effective on improving speaking skill.

\section{Discussion}

This study examined the effects of teaching DMs on improving Iranian EFL learners' speaking achievement. After analyzing the data, the results showed that there was not a significant difference between the performance of both experimental and control groups in the pre-test; moreover, there was not a significant difference between the performance of the two groups in the post-test. It can be concluded that both experimental and control groups performed equally on the post-test. In fact, teaching DMs did not affect the speaking achievement positively.

The reason of this result can be interpreted in terms of the explanation the experimental group received on the forms and functions of DMs during the course. However, in this regard the control group received traditional instruction, mainly examples. In the experimental group, the instructor clearly outlines what the learning goals are for the students, and offers unambiguous explanations of the skills and information structures the learners need. By traditional instruction, we refer to teaching where the instructor just gives examples and may explain the subject orally as what is currently used in conventional classrooms. The teachers teach the subject to the students and allow them to make their own conclusions and create their own conceptual structures and assimilate the information in the way that makes the most sense to them (Ellis, 1994). Therefore, both instructions were effective equally.

The previously conducted studies have revealed different results regarding the effectiveness of using DMs to improve EFL learners' speaking proficiency. Some researchers have found that using DMs can help learners to improve their language ability by allowing them thinking more and continuing to their speech with more self-confidence. However, they also believe that learners should not employ DMs such as gap-fillers too much. Learners should employ fillers in moderation since there is no certain rule in nervous mode or when learners need a short time to think about utterances (Dontcheva-Navratilova, 2012). Using fillers, in fact, does not indicate lack of intelligence or education. Nevertheless, according to some other researchers, using fillers by speaker reveals their weakness. In other words, frequent use of DMs and filers is regarded as a threat to the beauty, power, and effectiveness of verbal communication (Dastjerdi \& Shirzad, 2010). Innajih (2007) believed that all people, even famous public figures, frequently and sometimes excessively employ fillers. According to Chalak and Norouzi (2014), people employ DMs in nervous states or in case of feeling a need of time for thinking about upcoming sentences and words.

The present research findings were shown to be consistent with the results reported by Rajabi and Salami (2016), indicating that teaching gap-fillers does not influence Iranian intermediate learners' speaking performance. In this case, it was observed that speaking ability (fluency, accuracy, coherence, range, \& interaction) of the learners was not affected by using DMs. In fact, the learners found DMs employment as a time-consuming action in their spoken language production process. Also, Pazhakh and Karimi (2015) reported that explicit teaching of DMs affects all language skills since they are important components of language. However, Robby (2011) reported inconsistent results, indicating that learners can improve their speaking by using DMs like fillers since they found more time to think about and select upcoming words during speaking. 
The equal performance of the both groups in the post-test may be due to a main factor which is related to the participants' habit of learning which makes them dependent on the teachers, especially speaking. Thus, learners have a sense that they need the teachers' instruction and believe that this is the teacher who should solve all the problems. Since the participants of this study were at the intermediate level, due to this level they enjoyed some attributes. First, they were teacher-orientated. In the teacher-orientated classes, knowledge is only transmitted from the teacher to the students. In these classes, learning is not viewed as a cognitive act (Nunan, 1989). The other attribute of these lowlevel learners was the lack of self-autonomy. Autonomy is the idea of learning alone. Autonomous learners rely on their own learning. They attend to the form as well as to the content. Furthermore, an important factor that has to be taken into consideration for autonomous learners is language awareness (Dickinson, 1987). The third attribute of these intermediate learners was that they were field dependent. Field dependent learners tend to rely more on the teacher. They perceive field as a whole. In the classroom, activities that connect different parts of a lesson fused with background are useful for them. These learners are less skilled in interpersonal relationships and therefore, the chance of group learning is low for them (Ellis, 1994). The last attribute of these learners was that they required traditionalbased classes. Traditional language teaching has composed of three phases: presentation, practice, and production (Celce-Murcia, 2014).

\section{Conclusion}

In general, investigating the effect of teaching DMs on intermediate EFL learners' speaking achievement and willingness to communicate showed that using DMs had no significant effect on the learners' speaking ability. As their post-test mean scores proved, the learners' speaking was not affected by DMs. Similarly, comparing the performance of the learners in the WTC questionnaire before and after the treatment indicated that using DMs did not affect the learners' willingness to communicate. That is, the learners found DMs employment as a time-consuming action in their spoken language production process. In other words, the learners prefer to be silent and think instead of using DMs to fill their pauses. The learners spent time to find a discourse marker and subsequently their speed of speaking was reduced. It could be attributed to the level of their language knowledge and self-confidence, influencing their intrinsic motivation to employ DMs. In other words, if the learners have a good level of DMs and they stick in their mind, the learners can rapidly and easily find appropriate gambits without consuming too much time and disturbing the fluency, accuracy, and coherence of speaking.

Like all studies, this study had limitations and could not include all the issues related to the topic. They are as follows:

1. One limitation is that the study included only participants that were 16 to 19 years old. So, the results cannot be generalized to the other age groups.

2. The population was limited to 60 learners. Therefore, this cannot be generalized either.

3. The time allocated to the instruction was so limited.

4. The gender of the participants was limited to the female learners; therefore, the results of the study may not be generalizable to male learners.

5. Only one level (intermediate) of English students participated in this study. So, care must be exercised in generalizing the results beyond its proper limits.

6. The role of attitudes, anxiety level, and family situations of the participants were not controlled by the researchers.

7. The results of this study may be affected by classroom situation and social factors. These factors have not been taken into account in the present study.

In order to complement the findings of the present study, the next researches can be suggested:

1. Much empirical research is needed world-wide to further our understanding of the positive effects of the teaching DMs on speaking skill.

2. Similar studies are critically needed in other parts of Iran in order to see whether the results will be the same as or different from the results of the present study.

3. It would be beneficial to look at a larger sample of participants across a broader age range.

4. Next studies are advised to include both genders in order to gain more reliable results. 
5. The future studies are offered to examine the effects of teaching DMs on other skills and sub-skills of English language.

6. Future studies can be done on other proficiency levels, namely pre-intermediate, upper intermediate, and advanced.

7. The last suggestion for the next studies is to include more participants to get richer findings.

\section{References}

Asik, A., \& Cephe, P. T. (2013). Discourse markers and spoken English: Nonnative use in the Turkish EFL setting. English Language Teaching, 6(12), 144-159. doi: 10.5539/elt.v6n12p144

Blakemore, D. (1987). Semantic constrains on relevance. Oxford: Blackwell.

Brown, D. H. (2001). Principles of language learning and teaching. Englewood Cliffs. New Jersey: Prentice-Hall, Inc.

Burns, A., \& Joyce, H. (1997). Focus on speaking. Sydney: National Center for English Language Teaching and Research.

Carter, R., \& McCarthy, M. J. (2006). Cambridge grammar of English: a comprehensive guide to spoken and written grammar and usage. Cambridge: Cambridge UP.

Celce-Murcia, M. (2014). Teaching English as a second or foreign language ( $3^{\text {rd }}$ ed.). Boston: Heinle \& Heinle.

Chalak, A., \& Norouzi, Z. (2014). A contrastive analysis of English and Persian native speakers' use of gambits. Research in English Language Pedagogy, 2(1), 61-70. http://relp.khuisf.ac.ir/article 533607.html

Cullen, R., \& Kuo, I. C. (2007). Spoken grammar and ELT course materials: A missing link? TESOL Quarterly, 41(2), 361-386. https://doi.org/10.1002/j.1545-7249.2007.tb00063.x

Dastjerdi, H. V., \& Shirzad, M. (2010). The impact of explicit instruction of metadiscourse markers on EFL learners' writing performance. The Journal of Teaching Language Skills, 2(2), 1-15. https://www.magiran.com/paper/781388

De Klerk, V. (2005). Towards a corpus of Black South African English. Southern African Journal of Linguistics \& Applied Language Studies 20(1-2), 25-35. doi: 10.2989/16073610209486296

Dickinson, L. (1987). Self-instruction in language learning. Cambridge: Cambridge University Press.

Dontcheva-Navratilova, O. (2012). Discourse Interpretation: Approaches and Applications. Cambridge Scholars Publishing.

Ellis, R. (1984). Classroom second language development. Oxford: Pergamon.

Erman, B. (1987). Pragmatic expressions in English. A study of 'you know' you see' and 'mean' in face-to-face conversation. Stockholm studies in English 69. Stockholm: Almqvist and Wiksell.

Farhat, J., Asim Rai, M., \& Arif, S. (2011). A corpus based study of discourse markers in British and Pakistani speech. International Journal of Language $\quad$ Studies, $\quad 5(4), \quad 69-86$. https://www.researchgate.net/publication/260042226_A_corpus_based_study_of_discourse_markers_in_Bri $\underline{\text { tish_and_Pakistani_speech }}$

Fraser, B. (1990). An approach to discourse markers. Journal of Pragmatics 14(3), 383- 395. doi: 10.1016/0378$\underline{2166(90) 90096-\mathrm{V}}$

Fuller, J. M. (2003). The influence of speaker role on discourse marker use. Journal of Pragmatics, 35(1), 23-45. https://doi.org/10.1016/S0378-2166(02)00065-6

Fung, L., \& Carter, R. (2007). Discourse markers and spoken English: Native and learner use in pedagogic settings. Applied Linguistics, 28(3), 410-439. https://doi.org/10.1093/applin/amm030

Hellermann, J., \& Vergun, A. (2007). Language which is not taught: The discourse marker uses of beginning adult learners of English. Journal of Pragmatics, 39(1), 157-179. https://doi.org/10.1016/j.pragma.2006.04.008 
Innajih, A. (2007). The effect of conjunctive types on the English language reading comprehension of Libyan university students. [Online] Available: www.ecls.ncl.ac.uk/publish/text/TheEffectofConjunctive/.

Jarret, C. (2014). I mean, you know, I'm a conscientious person: links between use of "speech fillers" and personality. http://digest.bps.org.uk/2014/06/women-young-people-and-conscientious.html

Jones, C. (2010). Spoken discourse markers: What are they and why teach them? In Recent approaches to teaching and assessing speaking: Selected articles by the presenters of the IATEFL testing, evaluation and assessment special interest group conference in Famagusta, Cyprus 23-

24 October 2009 (pp. 84-89). IATEFL (TEA SIG).

Khaghaninejad, M. S., \& Mavadat, R. (2015). Using English discourse markers: a comparison of Persian and English dentistry authors. Theory and Practice in Language Studies 5(1), 97-109. http://dx.doi.org/10.17507/tpls.0501.13

Lam, P. W. Y. (2009). Discourse particles in corpus data and textbooks: The case of well. Applied Linguistics, 31(2), 260-281. doi: 10.1093/applin/amp026

Lazaraton, A. (2001). Teaching oral skills. In Celce-Murcia, M. (Ed), Teaching English as a second or foreign language (pp.102-115). New York: Heinle and Heinle.

Louwerse, M., \& Mitchell, H. H. (2003). Towards a taxonomy of a set of discourse markers in dialog: A theoretical and computational linguistic account. Discourse Processes, 35(2), 199-239. http://dx.doi.org/10.1207/S15326950DP3503_1

Luoma, S. (2004). Assessing speaking. Cambridge: Cambridge University Press.

McCarthy, M. (1993). Discourse analysis for language teachers. Cambridge University Press.

Muller, S. (2005). Discourse markers in native and non-native English discourse. John Benjamins Publishing Company.

Namaziandost, E., Hosseini, E., \& Utomo, D. W. (2020). A comparative effect of high involvement load versus lack of involvement load on vocabulary learning among Iranian sophomore EFL learners. Cogent Arts and Humanities, 7(1). https://doi.org/10.1080/23311983.2020.1715525

Namaziandost, E., Pourhosein Gilakjani, A., \& Hidayatullah (2020). Enhancing pre-intermediate EFL learners' reading comprehension through the use of Jigsaw technique. Cogent Arts \& Humanities, 7(1), 1-15. doi: $\underline{10.1080 / 23311983.2020 .1738833}$

Namaziandost, E., Rezvani, E., \& Polemikou, A. (2020). The impacts of visual input enhancement, semantic input enhancement, and input flooding on L2 vocabulary among Iranian intermediate EFL learners. Cogent Education, 7(1). doi: 10.1080/2331186X.2020.1726606

Namaziandost E., \& Shafiee, S. (2018). Gender differences in the use of lexical hedges in academic spoken language among Iranian EFL learners: a comparative study. International Journal of Research in English Education (IJREE), 3(4), 64-80. http://ijreeonline.com/article-1-130-en.html

Namaziandost, E., Shatalebi, V., \& Nasri, M. (2019). The impact of cooperative learning on developing speaking ability and motivation toward learning English. Journal of Language and Education, 5(3), 83-101. doi: https://doi.org/10.17323/jle.2019.9809

Nunan, D. (1989). Designing tasks for the communicative classroom. Cambridge: Cambridge University Press.

O’Keeffe, A., McCarthy, M., \& Carter, R. (2007). From corpus to classroom. Cambridge: Cambridge University Press.

Östman, J. O. (1981). You know: a discourse functional approach. Amsterdam: John Benjamins.

Pazhakh, A. R., \&Karimi, M. (2015). The effect of explicit teaching of discourse markers on Iranian EFL leaners' pragmatic fluency. Research and Analysis Journals, 1(1), 273-291. doi: 10.18535/ijmei/v1i6.04

Prodromou, L. (2008). English as a lingua franca: a corpus-based analysis. London: Continuum. 
Quirk, R. (1955). Colloquial English and communication. In B. Evans (ed.) Studies in Communication. London: Secker and Warbug.

Rajabi, P., \& Salami, S. N. (2016). Gap-fillers instruction and Iranian intermediate EFL learners' speaking performance. International Journal of Educational Investigations, 3(1), 78-85.

Sadeghi, B., \& Ramezan Yarandi, M. R. (2014). Analytical study on the relationship be-tween discourse markers and speaking fluency of Iranian EFL students. International Journal of Linguistics and Communication, 2(2), 101123.

Schiffrin, D. (1987). Discourse markers. Cambridge: Cambridge University Press.

Schourup, L. (1999). Discourse markers. Lingua, 107(3-4), 227-265. https://doi.org/10.1016/S0024-3841(96)90026$\underline{1}$

Simin, S., \& Tavangar, M. (2009). Metadiscourse knowledge and use in Iranian EFL writing. Asian EFL Journal, 11(4), 230-255. https://www.asian-efl-journal.com/main-editions-new/metadiscourse-knowledge-and-use-iniranian-efl-writing/

Sun, W. (2013). The importance of discourse markers in English learning and teaching. Theory and Practice in Language Studies, 3(11), 2136-2140. doi:10.4304/tpls.3.11.2136-2140

Timmis, I. (2005). Towards a framework for teaching spoken grammar. ELT Journal, 59(2), 117-125. https://doi.org/10.1093/eltj/cci025

Tsai, P. S., \& Chu, W. H. (2017). The use of discourse markers among mandarin Chinese teachers, and Chinese as a second language and Chinese as a foreign language learner. Applied Linguistics, 38(5), 638-665. https://doi.org/10.1093/applin/amv057

Webb, N. (1982). Student interaction and learning in small groups. Review of Educational Research, 52(3), 421-445. https://doi.org/10.2307/1170424

Wierzbicka, A. (1991). Cross-cultural pragmatics: the semantics of human interaction. Berlin: Mouton de Gruyter.

Wray, A. (2000). Formulaic sequences in second language teaching: Principles and practice. Applied Linguistics, 21(4), 463-489. doi: 10.1093/applin/21.4.463

Yazdizadeh, Z., Shakibaei G., \& Namaziandost, E. (2020). Investigating the relationship between Iranian undergraduate TEFL learners' self-regulation and self-efficacy. International Journal of Research in English Education (IJREE), 12-23. http://ijreeonline.com/article-1-308-en.html 